\title{
The Quality of College Student Party Members in the Perspective of Scholarship
}

\author{
Shuo Zhang ${ }^{1}$, Bin Liu ${ }^{2}$, Guishu Yu ${ }^{1}$ \\ ${ }^{1}$ Faculty of Infrastructure Engineering, Dalian University of Technology, Dalian, China \\ ${ }^{2}$ International School of Information Science \& Engineering, Dalian University of Technology, Dalian, China
}

Email address:

zhangshuo@dlut.edu.cn (Shuo Zhang), laohubinbin@163.com (Bin Liu), 1002535403@qq.com (Guishu Yu)

To cite this article:

Shuo Zhang, Bin Liu, Guishu Yu. The Quality of College Student Party Members in the Perspective of Scholarship-Example from DUT. Humanities and Social Sciences. Vol. 5, No. 5, 2017, pp. 171-175. doi: 10.11648/j.hss.20170505.12

Received: July 30, 2017; Accepted: August 31, 2017; Published: September 14, 2017

\begin{abstract}
The quality of college student party member is the core task work of development about college student party member, and will affect the future development of the Communist Party of China directly. In this paper, Dalian University of Technology student members is the object of study, and based on the scholarship, it analyzes the status quo of student party members in six aspects: academic achievement, spiritual civilization, social work, social practice, scientific and technological innovation and cultural and sports activities. It is shows that Party members get a higher proportion of scholarships than non-party members. The article also analyzes the difference of the quality of college student party members from three aspects: subject background, gender and grade. It shows great theoretical and practical significance to understand and master the quality of college student party members.
\end{abstract}

Keywords: Scholarship, Perspective, College Student Party Members

\section{Introduction}

The Quality of College Student Party Member is an important prerequisite and guarantee for the pioneer and exemplary Role of College Student Party Member. In the twelfth national college party building work conference, the former Ministry of Education Party Secretary, Minister Ji Zhou pointed out "College must strengthen and improve the work about College Student Party Members' development, and condenses the outstanding young students to the party ranks and career. It is an important measure about" Three Represents' important thinking. "Communist Party of China Organization Department, Propaganda Department, the CPC Ministry of Education Party Group in 2013 jointly issued the" opinions about strengthening of college student party members development (after referred to as "opinions"), it clearly pointed out that we should fully understand the importance of the development and education management services of college students. College should build a team about college student party members which has a strong faith, good quality, moderate scale, reasonable structure, strict discipline, the role of prominent. It can be seen that it is necessary to grasp the policy requirements of the party building work in the new situation and improve the quality of the party members. It is also the political need of the future and the future of the country. [1]

\section{The Importance of Quality Analysis of College Student Party Members}

Youth is the future of the motherland, as a good group of young people, the quality of college students will be directly related to the party building and development. It is an important basis for the development of college students' party members, which is about the future of the country and the success or failure of the nation. [2] At present, the quality of college student party members is a high degree of concern for universities and academia, and it is of great theoretical and practical significance to analyze the quality of college student Party members. 


\subsection{The Quality of College Student Party Members Is an Important Requirement to Test the Party Building Work in Colleges and Universities}

As an important part of the party building work, Party building in colleges and universities need to adjust according to the overall task of party building and the actual situation of party building. "Opinions" clearly pointed out that all local colleges and universities need to improve the quality of student members as the core from the overall and strategic height. It can be seen that the quality status of college student party members has become the most important indicator to test the party building work in colleges and universities. Therefore, the party building in colleges and universities should scientifically and objectively analyze the current situation, and constantly adjust the ways and means of the party building work in the light of the problems and shortcomings of the party building work, and further enhance the scientific and practical achievements of the party building work.

\subsection{The Quality of College Student Party Members Is an Important Basis for Evaluating the Development of College Student Party Members}

With the growing ranks of party members, party members also inevitably appear in the individual party spirit is weak, illegal and chaotic, bribery phenomenon. Most college students party members is thinking positive, requires progress, a higher overall quality. However, due to its shorter time to join the party and other reasons, there are still varying degrees of motivation to join the party impetuous, utilitarian strong and other issues. Therefore, the analysis of the quality of college students in the status quo can support the development of party members to provide data.

\subsection{The Quality of College Student Party Members Determines the Success or Failure of the Motherland}

Comrade Jintao Hu said: "A visionary nation, always focus on youth; a visionary party, always regarded youth as an important force to promote historical development and social progress. Our nation is such a nation, Our party is such a party." As party members in the new force, college students are the representative of outstanding students, played a vanguard and exemplary role. Their ideological and political quality, the overall quality of how, directly affect the goals of other college students, and relate to the success or failure of the motherland.

\section{The Feasibility of the Relationship Between College Student Party Members and the Scholarship}

With the continuous development of college students 'party building, both the party workers and the theoretical researchers all regard the quality of college student party members as the important research direction. The research content mainly involves the analysis of the quality of college students' party members Yuefeng (Wu, 2015). Path (Liwei Shi, Jinghong Sun, 2015) and so on. The research mainly adopts the methods of questionnaire survey and interview, and carries on the investigation to analyze the problems of the party members in the process of development, training and so on, aiming at the problems such as the party motive, the party consciousness, the party program and the pioneer exemplary role play. Survey was based on the subjective ideas for college students, and was lack of objective data analysis.

This paper breaks through the previous research methods, takes the students' members of Dalian University of Technology as the research object, analyzes the specific data of the students' scholarships of Dalian University of Technology from 2015 to 2016, and analyzes the current situation of college students' party members in learning achievement, spiritual civilization and social work, Social practice, scientific and technological innovation, cultural and sports activities and other aspects of the performance.

Dalian University of Technology Student Award is a comprehensive assessment of the quality of students, excellent scholarships are divided into excellent scholarships, spiritual scholarships, cultural and sports scholarships, social work scholarships, science and technology innovation scholarships and social practice scholarships. Individual scholarships define clear indicators and are selected in the form of quantitative scores. Therefore, the study of student students in the six aspects of the performance, can reflect the student party members in the school students in the advanced level, to measure the outstanding degree of student members. It has a certain degree of scientific and rational. However, the research does not cover students' motivation to join the party, ideological and political quality, party spirit and other issues.

The Analysis of the Status Quo of the Quality of College Student Party Members in the Perspective of Scholarship

\subsection{Party Members Get a Higher Proportion of Scholarships than Non-Party Members}

In order to analyze the quality status of student party members better, this paper calculates the proportion of six individual scholarships among student party members and non-student students, and calculates the proportion of students in the six individual cases, The difference between the winning prizes can be found, the student party members in the academic performance, spiritual civilization, social work, scientific and technological innovation, social practice and cultural activities six face-to-face award-winning ratio is higher than non-party members of the award-winning ratio. It largely reflects The Advanced Nature and Model of Student Party Members. (See table 1) 
Table 1. The analysis table about Dalian University of Technology 2015-2016 school year student members, non-party members outstanding student scholarship award ratio.

\begin{tabular}{|c|c|c|c|}
\hline Individual scholarships & $\begin{array}{l}\text { The proportion of Party } \\
\text { members receive scholarships }\end{array}$ & $\begin{array}{l}\text { The proportion of non-party } \\
\text { members receive scholarships }\end{array}$ & $\begin{array}{l}\text { The difference proportion } \\
\text { between them }\end{array}$ \\
\hline Academic achievement & $39.27 \%$ & $18.32 \%$ & $20.95 \%$ \\
\hline spiritual civilization & $31.30 \%$ & $7.77 \%$ & $23.53 \%$ \\
\hline Scientific and technological innovation & $10.05 \%$ & $3.56 \%$ & $6.43 \%$ \\
\hline social work & $20.96 \%$ & $4.43 \%$ & $16.53 \%$ \\
\hline social practice & $11.92 \%$ & $3.18 \%$ & $8.74 \%$ \\
\hline cultural and sports activities & $13.71 \%$ & $5.20 \%$ & $8.51 \%$ \\
\hline
\end{tabular}

\subsection{In Terms of Scholarly Scholarships and Learning Scholarships, the Percentage of Student Party Members Was Significantly Higher}

Spiritual scholarships are designed to reward outstanding students in terms of ideological awareness, moral accomplishment, collective attitudes, social morality, solidarity, respect for discipline and participation in various student activities. [3] One of the important participatory requests is the sort of student's democratic review. In accordance with the requirements of the incentive scheme, the top $40 \%$ of the students in the democratic review will be eligible to declare the scholarship of the year. Spiritual civilization scholarships also examine the students of the civilization of the bedroom health, blood donation and other types of students can reflect the moral and other aspects. [4] Student party members in this aspect of the award-winning ratio of $23.53 \%$ higher than non-student members, the performance of student members in the democratic appraisal link has a higher ranking, the students have a higher evaluation of student members. It shows that student party members have a good ideological and moral quality, strong collective concept, the more prominent mass basis.[5]

Learning Excellence Scholarships are designed to encourage students with outstanding academic performance. The course is based on the entire course (except for the individual and second class), the average score of the first test, and one or more of the courses Students who pass the make-up can not report the outstanding scholarships of the year. [6] The percentage of students who received scholarships was $20.95 \%$ higher than that of non-student members. It indicates that student members would learn as an important task and have a strong vanguard and exemplary role in this respect. [7]

\subsection{Student Party Members Are the Higher Overall Quality of the Higher Proportion of Outstanding Students}

This paper analyzes the number of students who have won the scholarships of the party students and non-party students, and calculated the proportion of the number of scholarships of the student party members and the non-student members to obtain the different number of scholarships. [8] It is found that the student party members get one, two, three, Four, five, six scholarships are higher than non-student members. At the same time, with the number of items, the more obvious this trend. Among them, the proportion of students who received a scholarship was 1.33 times higher than that of non-student students. The proportion of students who received six scholarships was 43.33 times that of non-student members, increasing by more than 40 times. It can be seen that the number of outstanding students with high overall quality in the group of student members is able to play a better role and lead.

Table 2. The number of items about student party members, non-party members to obtain outstanding student scholarships in Dalian University of Technology 2015-2016.

\begin{tabular}{|c|c|c|c|c|c|}
\hline Number & $\begin{array}{l}\text { Number of student } \\
\text { party members }\end{array}$ & $\begin{array}{l}\text { Proportion of student } \\
\text { party members }\end{array}$ & $\begin{array}{l}\text { Number of student } \\
\text { non-party members }\end{array}$ & $\begin{array}{l}\text { Proportion of student } \\
\text { non-party members }\end{array}$ & $\begin{array}{l}\text { Multiple of scholarship } \\
\text { between the tow }\end{array}$ \\
\hline One & 360 & $25.84 \%$ & 2564 & $19.36 \%$ & 1.33 \\
\hline Tow & 232 & $16.65 \%$ & 825 & $6.23 \%$ & 2.67 \\
\hline Three & 143 & $10.27 \%$ & 303 & $2.29 \%$ & 4.48 \\
\hline Four & 75 & $5.38 \%$ & 97 & $0.73 \%$ & 7.37 \\
\hline Five & 33 & $2.37 \%$ & 20 & $0.15 \%$ & 15.8 \\
\hline Six & 9 & $0.65 \%$ & 2 & $0.015 \%$ & 43.33 \\
\hline
\end{tabular}

\section{The Differences of the Quality of College Student Party Members in the Scholarship}

In order to analyze the status quo of the quality of student party members better, this paper analyzes the differences in the quality of scholarship students from the aspects of subject background, gender and grade, based on the award of excellent scholarships in 2015-2016 academic year.

\subsection{Discipline Background Differences}

\subsubsection{The Proportion of Science Class for the Five Individual Scholarships Is the Lowest}

Through the comparative analysis of science, engineering, liberal arts, management students in the corresponding student students, it is shows that in the six individual learning scholarship student membership award ratio, science Students in the academic performance, spiritual civilization, social work, scientific and technological innovation, social work, 
sports and sports activities are both the lowest proportion of scholarships, which is particularly prominent style of sports activities, higher than the highest proportion of liberal arts students 20.24 percentage points. It can be seen that, compared with other members of the students, science students party members in the study of greater pressure, need to continuously improve their overall quality.

Table 3. Analysis on the Proportion of Scholarships of Party Members in Various Universities in Dalian University of Technology $2015-2016$.

\begin{tabular}{|c|c|c|c|c|c|}
\hline Individual scholarships & $\begin{array}{l}\text { The proportion of } \\
\text { students in science }\end{array}$ & $\begin{array}{l}\text { The proportion } \\
\text { of students in } \\
\text { engineering }\end{array}$ & $\begin{array}{l}\text { The proportion of } \\
\text { students in liberal } \\
\text { arts }\end{array}$ & $\begin{array}{l}\text { The proportion of } \\
\text { students in } \\
\text { management }\end{array}$ & $\begin{array}{l}\text { The total } \\
\text { proportion }\end{array}$ \\
\hline Academic achievement & $16.82 \%$ & $18.17 \%$ & $18.40 \%$ & $22.22 \%$ & $18.40 \%$ \\
\hline spiritual civilization & $23.01 \%$ & $29.58 \%$ & $36.59 \%$ & $30.95 \%$ & $29.76 \%$ \\
\hline scientific and technological innovation & $17.78 \%$ & $22.15 \%$ & $24.24 \%$ & $32.35 \%$ & $22.88 \%$ \\
\hline social work & $29.41 \%$ & $32.64 \%$ & $48 \%$ & $32 \%$ & $33.22 \%$ \\
\hline cultural and sports activities & $11.76 \%$ & $21.46 \%$ & $32 \%$ & $26 \%$ & $21.73 \%$ \\
\hline
\end{tabular}

\subsubsection{In the Social Practice, Engineering Students Are the Lowest Proportion of Scholarships}

It can be seen from Table 3 that the proportion of the four individual scholarships in the various disciplines is higher than that of the social workers, the academic performance, the spiritual civilization, the scientific and technological innovation and the sports activities. In science students party members. The proportion of social practice is the lowest, only $26.95 \%$, higher than the highest proportion of liberal arts students party members $39.4 \%$ lower 12.45 percentage points, it can be seen, engineering students party members to constantly improve their social practice in the advanced nature, in order to better play the vanguard Exemplary role.

\subsubsection{The Proportion of Students in Management Class Is the Highest in Academic Achievement and Scientific and Technological Innovation}

It can be seen from Table 3 that the proportion of students in management and scientific and technological innovation is the highest, of which the winning percentage is $22.22 \%, 5.4$ percentage points higher than the lowest award science; the winning percentage of science and technology innovation is $32.35 \%$ higher than the lowest award-winning science 14.57 percentage points higher. It shows that the student members of the management class have a good learning atmosphere, pay attention to enhance their own scientific and technological innovation consciousness, in the study of scientific research has played a better vanguard and exemplary role.

\subsection{Gender Differences}

This paper analyzes the proportion of scholarships of female party members and female party members in the 2015-2016 school year. It can be seen that the winning proportion of male students and female party members in social practice and technological innovation is generally flat.

\subsubsection{Male Party Members in the Spiritual Civilization, Social Work Award Ratio Is Higher than the Female Party Members}

It can be seen from Table 4 that the proportion of male students in spiritual civilization and social work is better than that of female party members, which is $2.5 \%$ and $3.58 \%$ higher than female members respectively. To a certain extent, that boys and peasants in the masses of the foundation is better. They have more willing to serve the students in the spiritual civilization and social work to show better advanced.

Table 4. The proportion of scholarships of male students and female party members in Dalian University of Technology 2015 -2016.

\begin{tabular}{llll}
\hline Individual scholarships & Percentage of scholarships for boys & Percentage of scholarships for girls & $\begin{array}{l}\text { The ratio difference } \\
\text { between the tow }\end{array}$ \\
\hline Academic achievement & $29.22 \%$ & $33.29 \%$ & $-4.07 \%$ \\
spiritual civilization & $25.62 \%$ & $23.12 \%$ & $2.5 \%$ \\
scientific and technological innovation & $9.58 \%$ & $12.53 \%$ & $-2.95 \%$ \\
social work & $9.39 \%$ & $9.33 \%$ & $0.06 \%$ \\
social practice & $17.93 \%$ & $14.35 \%$ & $3.58 \%$ \\
cultural and sports activities & $8.25 \%$ & $7.38 \%$ & $0.87 \%$ \\
\hline
\end{tabular}

\subsubsection{In the Academic Performance, Cultural and Sports Activities, the Proportion of Female Party Members Is Than Male Party Members}

Through Table 4 shows that in the academic performance and cultural activities, the female party members are higher than boys, $4.07 \%$ and $2.95 \%$. The female party members will be more energy into the learning, at the same time, as the number of girls was significantly less than the number of boys and universities science and technology schools, female students to participate in cultural and sports activities of the enthusiasm is higher than the boys party members.

\subsection{Grade Difference}

It can be seen from Table 5 that, with the growth of grade, 
the proportion of students' scholarships has been increasing. The proportion of 2015 is the lowest, only $96.5 \%$, and the proportion of students in 2013 and 2014 is the highest, reaching $132 \%$. It can be seen that the higher the grade, the stronger the planning consciousness of the student party members, the stronger the advanced nature.

Table 5. The proportion of scholarships awarded by Dalian University of Technology in the 2015-2016 academic year.

\begin{tabular}{llll}
\hline Grade & Number of Party Members & Number of scholarships received by party members & Percentage of scholarships for party members \\
\hline 2011 & 838 & 1104 & $132 \%$ \\
2012 & 412 & 530 & $129 \%$ \\
2013 & 143 & 138 & $96.5 \%$ \\
\hline
\end{tabular}

\section{Conclusion}

In view of the above, the quality of college student party members is good, in the study, spiritual civilization, social work, scientific and technological innovation, social practice and cultural and sports activities have shown a good six advanced. But because of different subject background, different gender, they also show a certain difference. [9] For this, in the student members of the re-education, should be aimed at different groups, and constantly enrich the form of education, broaden the education channels, the educational connotation into the students loved sports activities, social practice, Volunteer service and other activities, to improve the attractiveness and effectiveness of party members education activities to enhance the quality of student members, and create a new situation of college students party building work. [10]

\section{Acknowledgements}

The article is one of the stage results of the reform project of Liaoning Provincial Department of Education (The research and practice of the mechanism of innovation and entrepreneurship education running through the whole process of personnel training).

The article is one of the stage results of 2017 Education and Teaching Reform Fund Project of the Dalian University of Technology (ideological and political education special) (A Study on the Method of Red Gene Integration into College Student Party Members No SZZD2017002).

The article is one of the stage results of Teaching Reform Fund Project of Dalian University of Technology (Construction of Multidimensional Practical Classroom Teaching Model for the Cultivation of Creative Ability Taking Graphic Image Processing Course as an Example, Item No. YB2017075).

\section{References}

[1] Li Y. Reflection and Practice on the Education of College Student Party Members in New Period [J]. Journal of Liaoning Provincial College of Communications, 2008.

[2] Zou X Y, Yong-Hui W U. On Problems in the Education of College Student Party Members and Solutions [J]. Journal of Anhui Agricultural University, 2009.

[3] Zhang J, Yang F, Marxism S O, et al. Combining the Education of Chinese Dream with the Ideological Education of College Student Party Members [J]. Journal of Guilin Normal College, 2016.

[4] Li, Xiuming, and S. Fang. "Improving the Quality of College Student Party Members in the Perspective of Political Socialization." Journal of College Advisor (2016).

[5] Chen, B. (2016). On path of college student party members' quality education. Journal of Changzhou Vocational College of Information Technology.

[6] Mills J N, Wolf P J. The Effects of the Louisiana Scholarship Program On Student Achievement after Two Years [J]. Social Science Electronic Publishing, 2016.

[7] Perna L W, Orosz K, Jumakulov Z. Understanding the human capital benefits of a government-funded international scholarship program: An exploration of Kazakhstan's Bolashak program [J]. International Journal of Educational Development, 2015, 40(40): 85-97.

[8] Schmiedeknecht, K., Perera, M., Schell, E., Jere, J., Geoffroy, E., \& Rankin, S. (2015). Predictors of workforce retention among malawian nurse graduates of a scholarship program: a mixed-methods study. Global Health Science \& Practice, 3(1), 85 .

[9] Lily, Abdulrahman Essa Al. "A Crowd-authoring Project on the Scholarship of Educational Technology." Information Development 32.5(2016).

[10] Shann, Steve. "A mythopoetic methodology: storytelling as an act of scholarship." Asia-Pacific Journal of Teacher Education 43.2(2015): 128-142. 